\title{
Intensity of heat stress in 2015 and 2018 summer seasons in the region of the Lower Silesia (Poland)
}

\begin{abstract}
The main goal of this paper was to assess the intensity of heat stress in Lower Silesia, Poland, during selected weather events characterized by high air temperatures. The complex impact of weather on the thermal load of the human organism is presented using the Universal Thermal Climate Index (UTCI). The analysis was carried out for the 2015 and 2018 summer seasons and compared with the multiannual period of 1971-2018. It was based on meteorological data from the IMGW-PIB stations of Wrocław, Jelenia Góra and Śnieżka. In order to examine how heat conditions affect UTCI in different geographical regions, stations located at different altitudes and representing the lowlands, the lower mountain zone and the summit zone of the Sudetes Mountains were considered. The research showed that during the most extreme thermal events, UTCI values in the lowlands and the lower mountain zones can be among the highest heat stress classes. In the summit zone, the maximum UTCI values are usually classed as 'no thermal stress'.
\end{abstract}

Keywords

Bioclimate $\bullet$ heat stress $\bullet$ UTCI $•$ Lower Silesia $•$ south-west Poland

(c) University of Warsaw - Faculty of Geography and Regional Studies

Introduction

One of the latest world climate reports showed that the last years of the current decade have been some of the warmest in the history of meteorological observations. The 2019 WMO report concluded that 2015-2018 were four of the warmest years ever since records have been kept. The high air temperature values over the last few years were especially noticeable in 2015 and 2018. The summer of 2015 was ranked as one of the most extreme thermal periods in the last few decades in Europe (Russo 2015) and concerned central Europe in particular. In some regions of Germany, Austria, the Czech Republic (Czechia) and Poland, thermal records were broken (Hoy et al. 2017; Muthers, Laschewski \& Matzarakis 2017; Krzyżewska, Wereski \& Demczuk 2019). Record high temperatures were also observed in some states of western and southern Europe, namely Switzerland, Italy and Spain (Ragettli et al. 2016; Hoy et al. 2017; lonita et al. 2017). In central Europe, the mean air temperature in the summer of 2015 exceeded the multiannual value by $2.4^{\circ} \mathrm{C}$ (Dong et al. 2016). An exceptionally warm summer was also recorded in 2018 (Kornhuber et al. 2019; Tomczyk \& Bednorz 2020). In Poland, the mean temperature in August 2018 was $2.7^{\circ} \mathrm{C}$ higher than for the 1966-2018 period (Tomczyk \& Bednorz 2020). Such thermal conditions often contributed to heatwave occurrences (Dong et al. 2016; Sulikowska, Wypych \& Woszczek 2016; Krzyżewska \& Dyer 2018; Urban et al. 2017; Wibig 2018), which are very unfavourable conditions that affect the human organism.

Lower Silesia is located in south-west Poland and is a popular tourism region. Most of the region consists of lowlands; however, the southern part of the area is covered by a mountain foreland and the Sudetes Mountains, the highest peak being Śnieżka. During recent decades, weather conditions related

\author{
Bartłomiej Miszuk 드
}

Institute of Meteorology and Water Management National Research Institute, Wrockaw, Poland e-mail: Bartlomiej.Miszuk@imgw.pl

Received: 17 March 2020 Accepted: 23 June 2020

to heat stress have frequently been observed in the lowlands. The summer seasons of 2015 and 2018, when thermal records were reached in most of the region under discussion, are good examples of such periods. Very high air temperatures contributed to an increase in biometeorological indices, including Universal Thermal Climate Index (UTCl). This is currently a popular biometeorological tool and was used in the evaluation of biothermal conditions in numerous European states, including the Czech Republic (Novak 2013; Urban \& Kyselý 2014), Germany (Matzarakis, Muthers \& Rutz 2014), Greece (Bleta, Nastos \& Matzarakis 2014) and Serbia (Pecelj et al. 2017). Further papers also presented the impact of heat stress, in terms of UTCI, on mortality rate (Urban \& Kyselý 2014; Błażejczyk et al. 2018; Di Napoli, Pappenberger \& Cloke 2018). In Poland, evaluations of UTCl have been carried out for the entire country (Błażejczyk \& Kunert 2011; Kuchcik et al. 2013; Błażejczyk et al. 2018; Tomczyk \& Owczarek 2020) or for particular regions, such as Warsaw (Lindner-Cendrowska 2013; Błażejczyk et al. 2014; Rozbicka \& Rozbicki 2018), the coastal region (Chabior 2011; Kolendowicz et al. 2018), south-east Poland (Nowosad et al. 2013; Bartoszek et al. 2017) and the Tatra Mountains (Błażejczyk \& Kunert 2010; Błażejczyk et al. 2013). In the case of the lowlands of Lower Silesia, research was related to the evaluation of UTCl in the suburban area of Wrocław (Bryś \& Ojrzyńska 2016) and Legnica (Sobolewski 2018). In the Sudetes Mountains, analysis concerned the variability of UTCI, based on geographical factors and land use (Milewski 2013) and the assessment of tourism potential in the Western Sudetes (Miszuk et al. 2016). The studies showed that the lowlands and lower mountain zones of Lower Silesia are vulnerable to heat stress occurrences in the summer. During heatwaves, usually occurring 


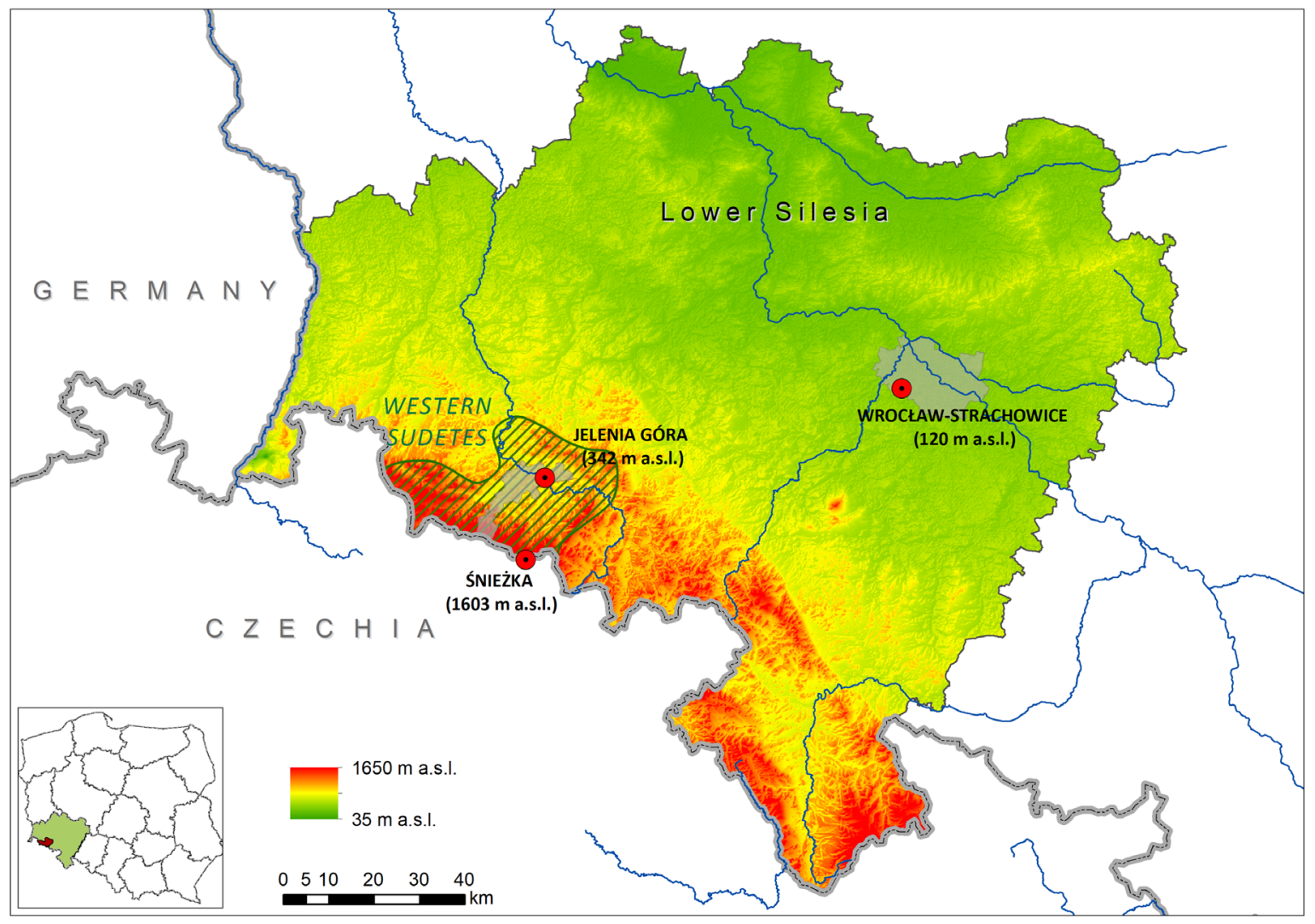

Figure 1. Location of the Wrocław-Strachowice, Jelenia Góra and Śnieżka meteorological stations. Source: own study.

under south-east circulation conditions, UTCI in the lowlands and lower zones of the Sudetes Mountains can exceed $40^{\circ} \mathrm{C}$ (Kuchcik et al. 2013; Bryś \& Ojrzyńska 2016).

Therefore, the main goal of this paper was to examine the intensity of heat stress during selected weather events, characterized by high air temperatures, in the summer seasons of 2015 and 2018 using UTCl and synoptic analysis. In order to examine how weather events (defined as heat conditions) in the lowlands affect bio-thermal conditions in the mountains, a comparison between the lowlands, the lower mountain areas and the summit zone of the Sudetes Mountains was carried out. The results of the analysis can be considered in tourism plans and investments.

\section{Data and Methods}

The analysis of biometeorological conditions was carried out using meteorological data for 1971-2018 from IMGW-PIB stations located in Wrocław, Jelenia Góra and on Śnieżka, which included air temperature, relative humidity, vapour pressure, wind speed and cloudiness. The data related to the 12.00 UTC period because of high human activity during daytime hours. However, in order to present the daily courses of UTCI in 2015 and 2018, data for the main synoptic terms $(0.00,3.00,6.00,9.00,12.00$, $15.00,18.00$ and 21.00 UTC) were also used. Additionally, in the context of the assessment of the radiation factor, data related to the sun angle for particular days were also taken into account.

The three meteorological stations considered in the paper represented various geographical regions of Lower Silesia (Fig. 1). They were located in the lowlands at $120 \mathrm{~m}$ a.s.l. (WrocławStrachowice), in the lower mountain zones at $342 \mathrm{~m}$ a.s.l.
(Jelenia Góra) and in the summit zone of the Sudetes Mountains at $1603 \mathrm{~m}$ a.s.l. (Śnieżka).

The main tool used in the paper was UTCl which is based on multi node models, mainly on Fiala's model (Fiala, Lomas \& Stohler 2001). The description of UTCl is presented in detail in publications concerning this index (i.e. Błażejczyk et al. 2010; Jendritzky, de Dear \& Havenith 2012). UTCI classifies weather conditions into ten different thermal stress categories. The structure of the stress categories, according to UTCI, is presented in Table 1.

Calculations of UTCI were carried out using the BioKlima2.6 software package (Institute of Geography and Spatial Organization 2020). The results of the UTCI values and the frequency of its categories (for 12.00 UTC) for June-August 2015 and June-August 2018 were compared to mean values for 1971-2018.

For some days of the 2015 and 2018 summer seasons, courses for air temperature and UTCI were presented in order to show the changes in heat stress classes during hot periods that lasted several days. Additionally, synoptic analysis was carried out in order to assess what the synoptic situation had contributed to the heat stress events. This analysis considered synoptic charts for sea level pressure and the higher zones of the troposphere (isobaric surfaces of $850 \mathrm{hPa}, 500 \mathrm{hPa}$ and 300 $\mathrm{hPa})$.

\section{Results}

The research showed that in terms of heat stress occurrence, the summer seasons of 2015 and 2018 were characterized as two of the most extreme in the 1971-2018 period. The mean daily air temperature in these summer seasons reached $20.5^{\circ} \mathrm{C}$ and $20.8^{\circ} \mathrm{C}$ in Wrocław, $18.3^{\circ} \mathrm{C}$ in Jelenia Góra (for both seasons) 
MISCELLANEA GEOGRAPHICA - REGIONAL STUDIES ON DEVELOPMENT

Vol. 24 • No. 3 • 2020 • pp. 138-146 • ISSN: 2084-6118 • DOI: 10.2478/mgrsd-2020-0020

Table 1. Stress category according to UTCI

\begin{tabular}{|c|c|}
\hline Stress category & UTCI $\left[{ }^{\circ} \mathrm{C}\right]$ \\
\hline Extreme heat stress & above 46 \\
\hline Very strong heat stress & 38 to 46 \\
\hline Strong heat stress & 32 to 38 \\
\hline Moderate heat stress & 26 to 32 \\
\hline No thermal stress & 9 to 26 \\
\hline Slight cold stress & 0 to 9 \\
\hline Moderate cold stress & -13 to 0 \\
\hline Strong cold stress & -27 to -13 \\
\hline Very strong cold stress & -40 to -27 \\
\hline Extreme cold stress & below -40 \\
\hline
\end{tabular}

Source: Błażejczyk et al. 2010

and $10.6^{\circ} \mathrm{C}$ and $10.5^{\circ} \mathrm{C}$ on Śnieżka; whereas mean values for $1971-2018$ amounted to $18.1^{\circ} \mathrm{C}, 16.2^{\circ} \mathrm{C}$ and $8.4^{\circ} \mathrm{C}$, respectively. The mean UTCI for 12.00 UTC in the summer of 2015 was $24.9^{\circ} \mathrm{C}$ in Wrocław, $22.3^{\circ} \mathrm{C}$ in Jelenia Góra and $3.1^{\circ} \mathrm{C}$ on Śnieżka, while in 2018 the figures reached $26.0^{\circ} \mathrm{C}, 23.6^{\circ} \mathrm{C}$ and $3.0^{\circ} \mathrm{C}$. Therefore, the values were higher than in $1971-2018$ by about $3-5^{\circ} \mathrm{C}(2015)$ and $4-5^{\circ} \mathrm{C}(2018)$.

In both seasons, the highest differences in mean values of UTCI, against the multiannual period, were observed for August (Fig. 2). In 2015, it was $5.7-9.1^{\circ} \mathrm{C}$ while in 2018 it reached 5.4$8.1^{\circ} \mathrm{C}$. The highest differences occurred on Śnieżka as a result of high air temperature and low wind speed (lower by about $2 \mathrm{~m} / \mathrm{s}$ compared with 1971-2018).

The general structure of thermal stress, according to UTCI, shows significant differences between the lower hypsometric zones and the summit area of the Sudetes. In the lowlands and the lower mountain parts, the 'no thermal stress' category usually dominates in the summer season. In 1971-2018, its mean seasonal frequency exceeded 50 days. In terms of heat stress, about 10-20 days are characterized by 'moderate heat stress' while 'strong heat stress' occurs on 3-6 days. Cold stress is mainly represented by the 'slight cold stress' category. In 1971-2018, this was recorded for more than 10 days a season. 'Moderate cold stress' usually occurs on 1-2 days. During the most extreme thermal events, 'very strong heat stress' occasionally appeared in Wrocław and Jelenia Góra. In the summer seasons of 2015 and 2018, the number of days of cold stress and thermoneutral conditions was lower, while the frequency for all of the classes related to heat stress increased (Fig. 3).

In the summit zone of the Sudetes (Śnieżka), cold stress was the prevailing category in the summer seasons of 1971-2018. 'Moderate cold stress' was the most frequent (24 days), while 'slight cold stress' and 'strong cold stress' occurred on 19 days. The mean number of 'very strong cold stress' and 'extreme cold stress' days came to 10 and 2, respectively. Weather conditions related to 'no thermal stress' occurred on 17 days. In terms of heat stress, one case of 'moderate heat stress' was recorded during the whole 1971-2018 period. The most distinctive issue on Śnieżka in 2015 and 2018 was the increase in frequency of 'no thermal stress' and 'moderate cold stress', while a lower number of days with a higher intensity of cold stress (very strong and strong cold stress) was observed. In the summer of 2015 and 2018, 'moderate cold stress' and 'no thermal stress' prevailed. In 2015 , these occurred on 21 days and 32 days, while their frequency in 2018 was 32 days and 28 days.

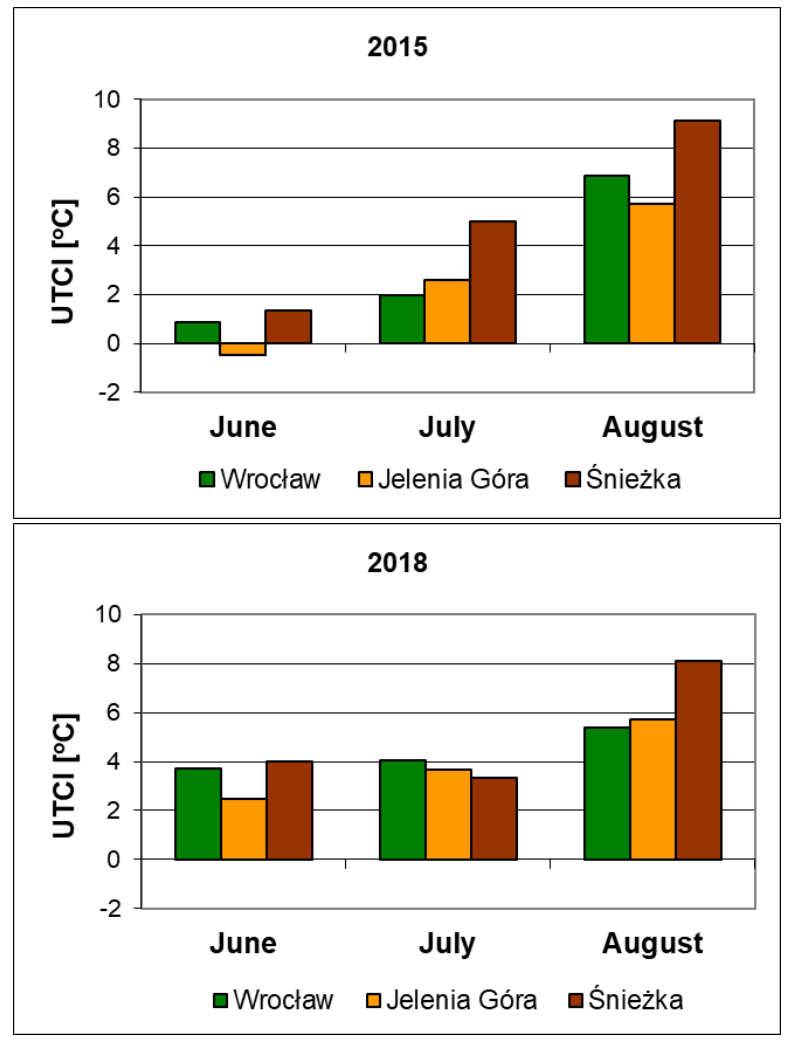

Figure 2. Differences in UTCI for 12.00 UTC between 2015, 2018 and the 1971-2018 period for June, July and August in Wrocław, Jelenia Góra and Śnieżka. Source: own study

One of the most distinctive features of the summer seasons discussed were weather conditions characterized by many days when maximum air temperature exceeded $30^{\circ} \mathrm{C}$ or even $35^{\circ} \mathrm{C}$. Such conditions were recorded in the lowlands and lower mountain zones of the discussed region (i.e. in Wrocław and Jelenia Góra). During these periods, UTCl values often fell into heat stress classes, including 'very strong heat stress'. In order to show the course of UTCI for such days, two heat weather conditions were selected: 8-10 August 2015 and 31 July 3 August 2018.

On 8-10 August 2015, the region of Lower Silesia was found to be within a low-pressure area that lay between a highpressure area from south-western Russia and the Azores High in the west that reached as far as the North Sea (Fig. 4). During those days, a cold front stretched from Finland and the Baltic Sea to Spain and the Western Mediterranean Sea. It separated tropical air advecting over central Europe and cool maritime polar air masses.

In the higher parts of the troposphere, the discussed region was covered by a high-pressure ridge reaching from Africa to south-western Russia. Meanwhile, a deep low-pressure trough moved slowly towards western Europe. Such pressure distribution generated south-west circulation over Lower Silesia and consequently the advection of tropical air masses from the north-west of Africa. At the isobaric level of $850 \mathrm{hPa}$, this was reflected in very high air temperature values. The area of south-western Poland that included Lower Silesia was within the isotherm of $20^{\circ} \mathrm{C}$. On 9 August, a high moved from the North Sea towards Sweden, while the high-pressure area over Russia weakened. As a result, the cold front moved to Poland, enabling the advection of cool maritime polar air masses to the north part of 

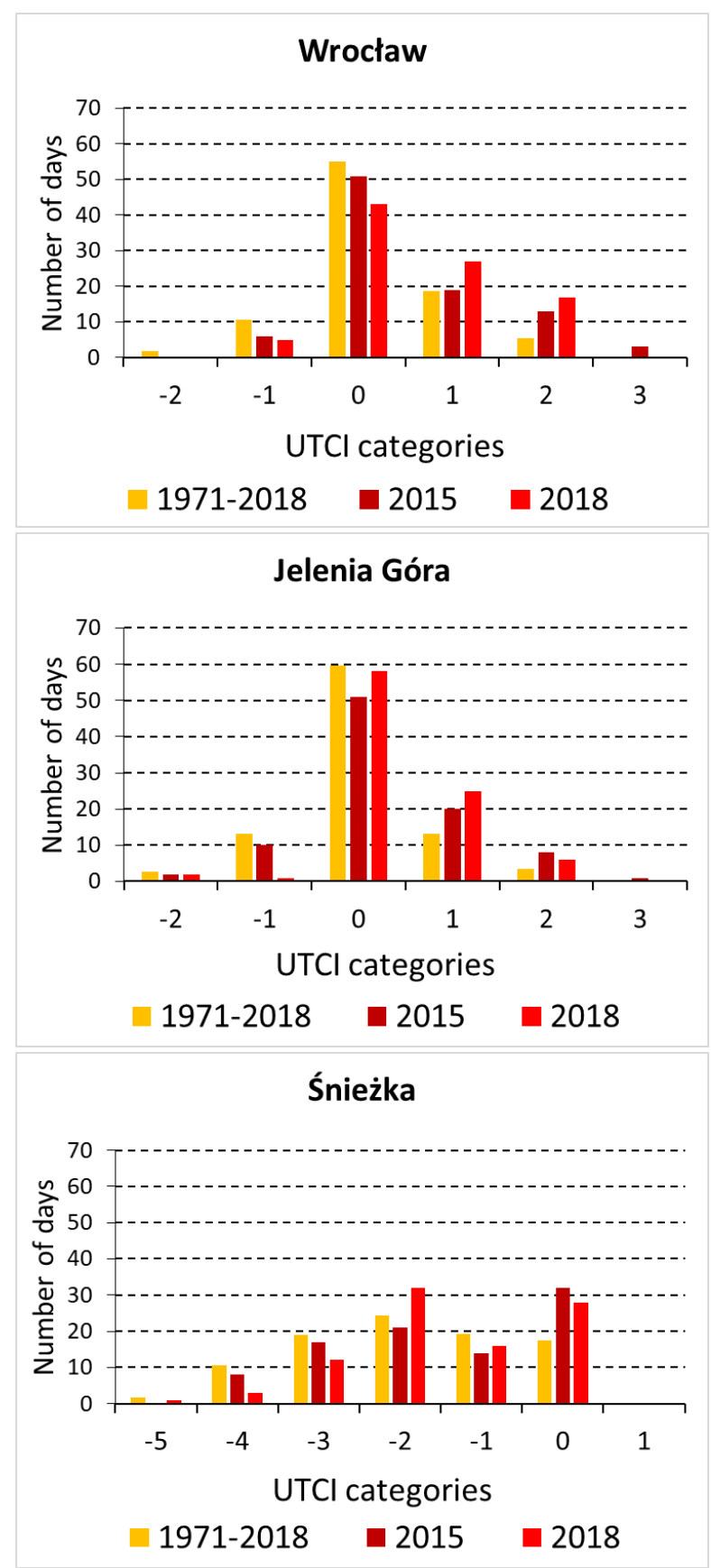

Figure 3. Frequency of thermal stress in the summer season (June-August) for 12.00 UTC in 1971-2018, 2015 and 2018 in Wrocław, Jelenia Góra and on Śnieżka, according to UTCI categories: extreme cold stress (-5), very strong cold stress (-4), strong cold stress (-3), moderate cold stress (-2), slight cold stress (-1), no thermal stress (0), moderate heat stress (1), strong heat stress (2), very strong heat stress (3). Source: own study

the state. However, the rest of Poland was still under the influence of tropical air masses. In the middle and upper troposphere, there was a low-pressure area that moved from France towards the Mediterranean Sea on 10 August. This low-pressure area, along with another one from Greece and the Adriatic Sea, developed a vast trough over southern Europe, which consequently disabled the advection of tropical air masses from Africa to central Europe.
On 10 August, the north of Poland was under the influence of maritime polar air masses, while transforming tropical air masses still covered the southern regions, including Lower Silesia. As a result of such a baric situation, very high air temperature values were observed in the region under discussion. On 8 August, thermal records were observed in Wrocław and Jelenia Góra where maximum air temperatures reached $37.9^{\circ} \mathrm{C}$ and $35.8^{\circ} \mathrm{C}$, respectively. On Śnieżka, the highest value exceeded $24^{\circ} \mathrm{C}$. In the lowlands and the lower mountain parts, maximum air temperatures on 9 August and 10 August were also very high. Due to such extreme air temperatures, high UTCI values were recorded throughout the period (Fig. 5). UTCI usually exceeded $32^{\circ} \mathrm{C}$ every day which placed it in the 'strong heat stress' category. On the first of those days, maximum UTCl values in Wrocław and Jelenia Góra were $40.6^{\circ} \mathrm{C}$ and $39.0^{\circ} \mathrm{C}$, respectively; bio-thermal conditions were classed in the "very strong heat stress' category. In the night-time, 'no thermal stress' was usually observed. Different conditions were observed on Śnieżka. Due to lower air temperature and high wind speed reaching $10 \mathrm{~m} / \mathrm{s}$, the 'no thermal stress' category was observed during the daytime, while in the night 'slight cold stress' occurred.

In the summer season of 2018 , one of the most extreme periods from a thermal point of view took place at the turn of July and August (31 July - 3 August). Over those days, the eastern part of Europe was under a high that moved from the north-west of Russia to Belarus (Fig. 6). Weather conditions over western Europe were determined by a low-pressure area from the north Atlantic Ocean. A cold front moved slowly from the west towards central Europe. It separated the advection of hot tropical air masses from the south and cool maritime polar masses behind the front. On 2 August, the front started affecting weather conditions in the north-west of Poland and moved further to the south-east. The tropical air was substituted by maritime polar masses.

On 31 July, in the middle and upper troposphere, the northwest of Europe was in a low-pressure area with its centre located south of Iceland and reaching the Iberian Peninsula. On the other side, a vast high-pressure ridge covered the region from Africa through central Europe to western Russia. Such pressure distribution generated the advection of tropical air masses from the south and south-west. In the following days, the upper baric field transformed. The low over western Europe filled while the high-pressure area from Africa significantly developed. In the east, the high-pressure ridge over Russia was weakened and the low-pressure trough from the Arctic deepened. Consequently, there was a change in circulation over Lower Silesia from south to west. Thus, the advection of maritime polar air masses began, substituting the tropical masses. As a result of the advection of tropical air masses, air temperature and UTCl in the lowlands and the lower mountain zone were characterized by high values (Fig. 7). Similar to the case previously discussed, the air temperature was higher than $30^{\circ} \mathrm{C}$. Maximum daily values for 31 July -3 August in Wrocław and Jelenia Góra exceeded $33^{\circ} \mathrm{C}$ and $32^{\circ} \mathrm{C}$. Air temperature on Śnieżka exceeded $19^{\circ} \mathrm{C}$ during the daytime (1 August), while it decreased to $14.4^{\circ} \mathrm{C}$ in the night. In terms of UTCI, 'strong heat stress' dominated in the lowlands and lower mountain zones during daily hours, while minimum UTCI was classified as 'no thermal stress'. In case of Śnieżka, relatively low air temperature and high wind speed (up to $11 \mathrm{~m} / \mathrm{s}$ ) contributed to a decrease in UTCI. Its maximum values were classed in the 'no thermal stress' category and its minimum values were recorded as 'slight cold stress'.

\section{Discussion and Conclusions}

The results presented show that the summer seasons of 2015 and 2018 were some of the most extreme periods in the last 


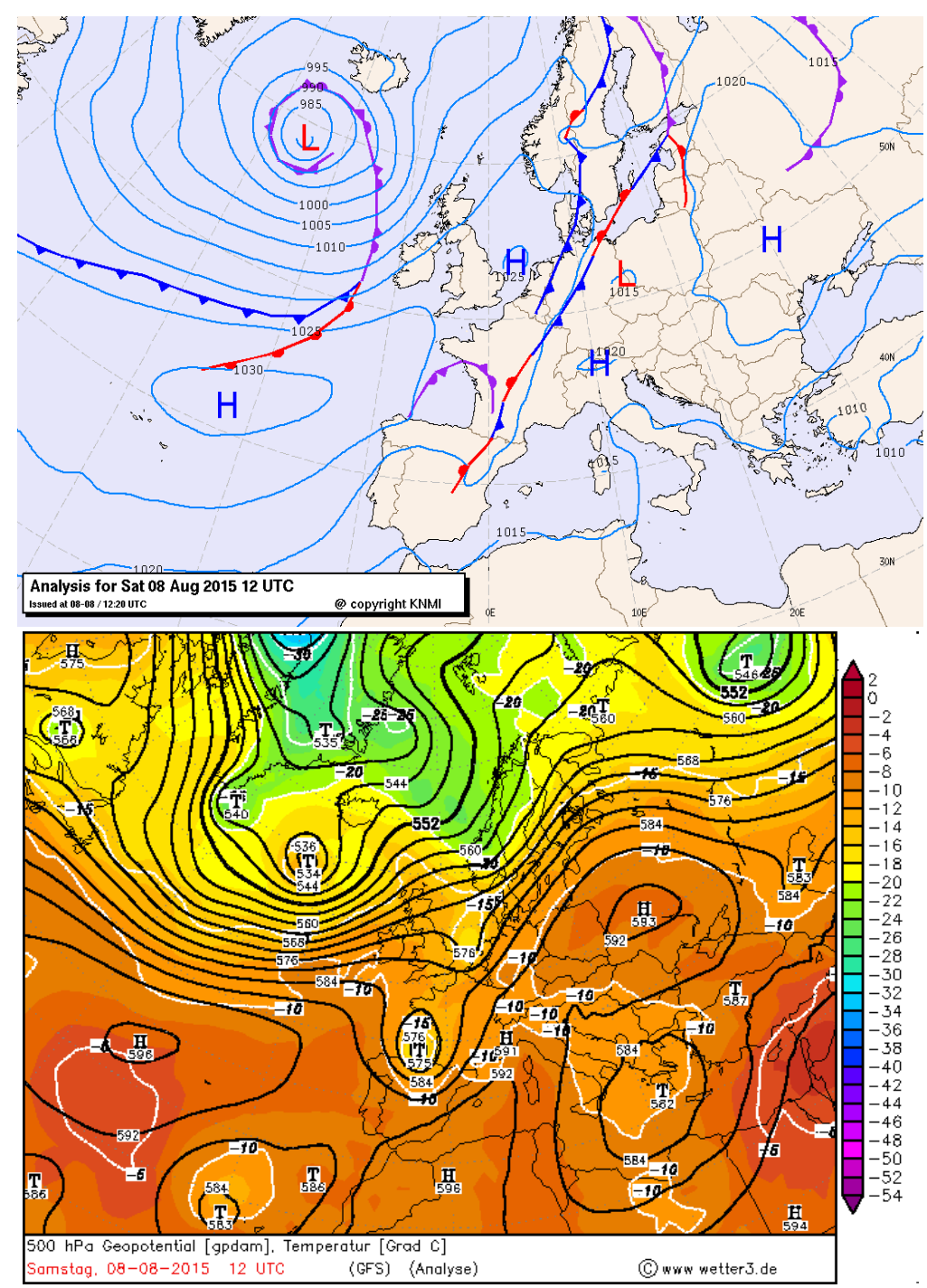

Figure 4. Synoptic situation over Europe on 8 August 2015, including sea level pressure field (left) and isobaric surface of $500 \mathrm{hPa}$ (right). Source: The Royal Netherlands Meteorological Institute; www.wetter3.de (R. Behrendt, H. Mahlke) (according to the conditions given by the map's authors)
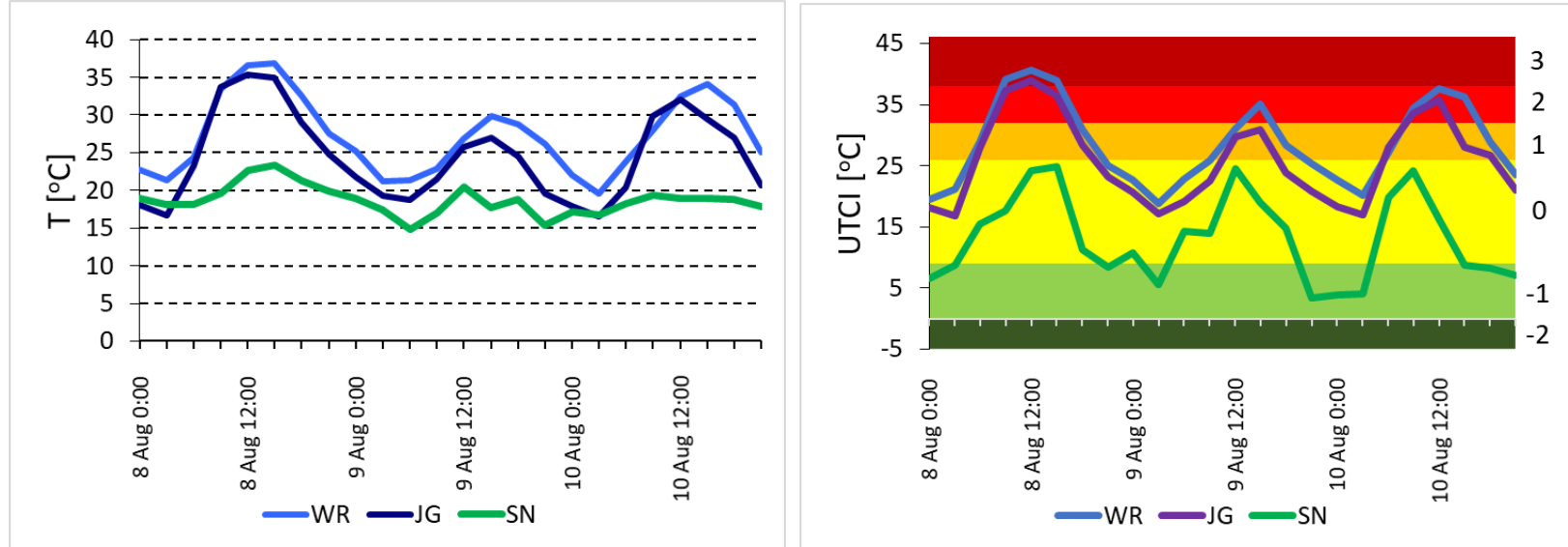

Figure 5. Course of air temperature (left) and UTCI (right) on 8-10 August 2015 in Wrocław (WR), Jelenia Góra (JG) and on Śnieżka (SN); UTCI categories: moderate cold stress (-2), slight cold stress (-1), no thermal stress (0), moderate heat stress (1), strong heat stress (2), very strong heat stress (3). Source: own study 


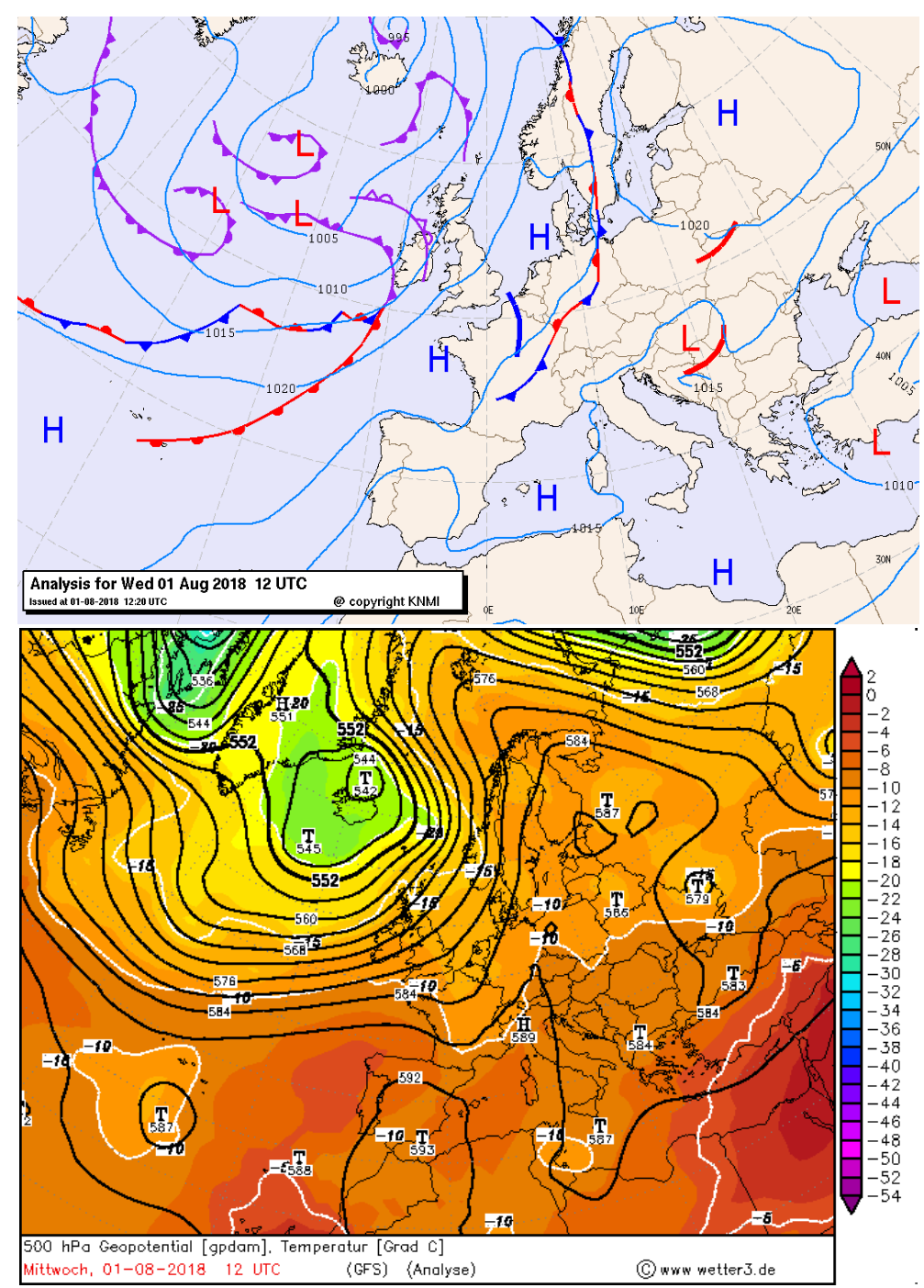

Figure 6. Synoptic situation over Europe on 1 August 2018, including sea level pressure field (left) and isobaric surface of $500 \mathrm{hPa}$ (right). Source: The Royal Netherlands Meteorological Institute; www.wetter3.de (R. Behrendt, H. Mahlke) (according to the conditions given by the map's authors)
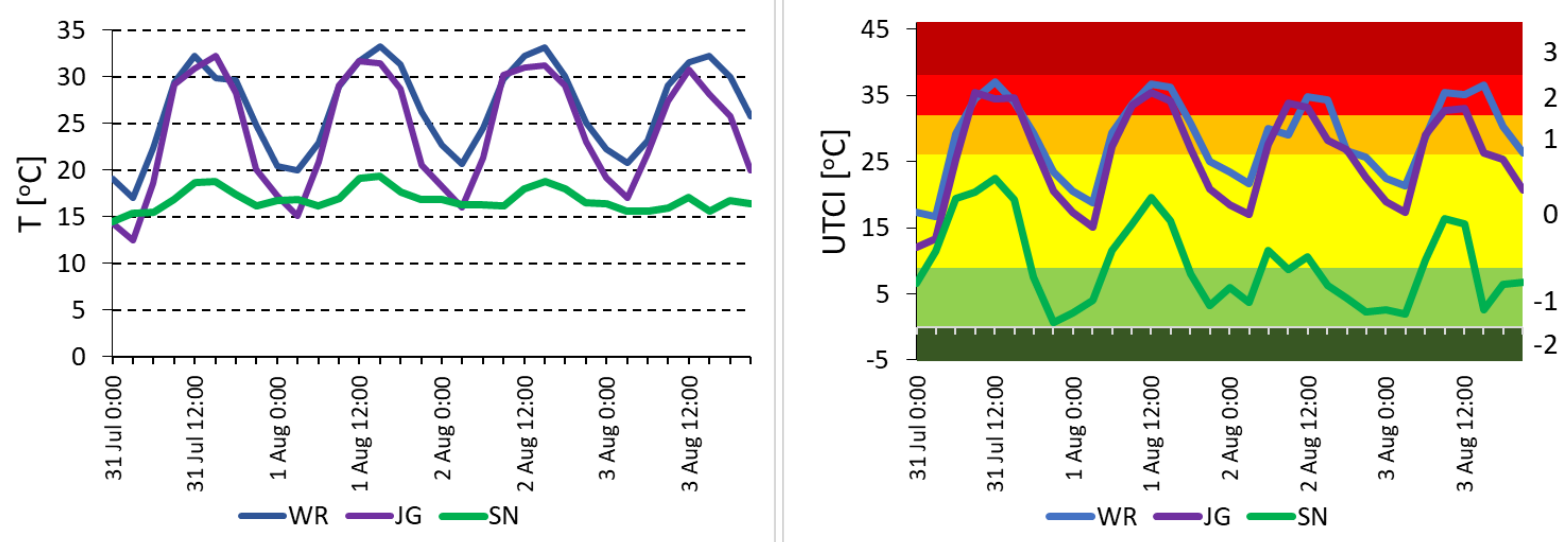

Figure 7. Course of air temperature (left) and UTCI (right) on 31 July - 3 August 2018 in Wrocław (WR), Jelenia Góra (JG) and on Śnieżka (SN); UTCl categories: moderate cold stress (-2), slight cold stress (-1), no thermal stress (0), moderate heat stress (1), strong heat stress (2), very strong heat stress (3). Source: own study 
half century in terms of bio-thermal conditions. A high intensity of heat stress was observed, especially in the lowlands and lower mountain parts of the Sudetes Mountains. The UTCI values were even classified in the 'very strong heat stress' category that had been observed sporadically in the past in the lowlands during extreme heatwaves; for example, in July 2010 (Bryś \& Ojrzyńska 2016). In Poland, this type of thermal stress occasionally occurs in the summer, especially during the southern circulation and advection of tropical air masses (Chabior 2011; Nowosad et al. 2013; Bartoszek et al. 2017; Rozbicka \& Rozbicki 2018). The most extreme conditions, from a bio-thermal perspective, occurred during anticyclonic types of weather. They can be defined as southerly anticyclonic circulation (AS, ASE, ASW) over central Europe (Plavcová \& Kyselý 2016). The selected cases of heat weather in 2015 and 2018 confirmed that a high-pressure system often contributes to the occurrence of strong and very strong heat stress, because of blocking zonal circulation (Wibig 2018; Tomczyk \& Owczarek 2020). A relation between strong anticyclonic conditions and heat stress occurrences was also observed for heatwaves in 2003 (Black et al. 2004; Garcia-Herrera et al. 2010).

Daily course and UTCI values in the lowlands, during the most extreme thermal events, were similar to those recorded in Prague in the Czech Republic, where UTCI can exceed $40^{\circ} \mathrm{C}$ on hot days (Novak 2013). In addition, the mean UTCI for 12.00 UTC for the summer seasons of 2015 and 2018 were about $1-3^{\circ} \mathrm{C}$ (Wrocław) and $3-6^{\circ} \mathrm{C}$ (Jelenia Góra) lower than the multiannual values for the summer in the main municipalities of Hungary (Nemeth 2011). In the case of Jelenia Góra, maximum UTCI values in the summer of 2015 and 2018 were comparable with maximum UTCI for the foothills of the Tatra Mountains (Zakopane) where it exceeded $37^{\circ} \mathrm{C}$ (Tomczyk \& Owczarek 2020). Mortality rates, related to cardiovascular issues, significantly increase when UTCl exceeds $32^{\circ} \mathrm{C}$ (Błażejczyk et al. 2018; Di Napoli, Pappenberger \& Cloke 2018; Tomczyk \& Owczarek 2020). Thus, the impact of weather conditions on the human organism during such extreme thermal periods can pose a risk to human health and life in the lowlands and lower mountain zones. It should be also emphasized that during hot, calm and sunny weather, UTCI in urban areas, even in the lower mountain zones of the Sudetes, can significantly increase and be classed as extreme heat stress conditions (Milewski 2013).

Unlike the areas located lower down, the summit zone of the Sudetes was not affected by heat stress, even in the most intensive heat periods. Despite thermal records observed in the regions located lower down, bio-thermal conditions on Śnieżka were usually classed as 'no thermal stress'. It confirms that the summit zone of the Sudetes is free from the occurrence of heat stress. In these terms, the summit zone is a more favourable region than, for example, the highest parts of the Zlatibor Mountains in southern Europe, where moderate heat stress quite often occurs in the summertime (Pecelj et al. 2017). On the other hand, the results for Śnieżka are comparable with the highest alpine zones where the structure of heat stress categories (assessed using the PET index) is similar (Ketterer \& Matzarakis 2010; Matzarakis et al. 2012).

In the case of the Lower Silesia, the research confirmed previous results for this region, indicating that the most extreme thermal events are related to southern circulation and are accompanied by a UTCI that exceeds $40^{\circ} \mathrm{C}$ in the lowlands (Bryś \& Ojrzyńska 2016). High vulnerability to heat stress was also recorded in the lower mountain zones, which conforms to the results carried out for 1971-2010 for this area (Miszuk et al. 2016). Maximum UTCI values were classified as 'very strong heat stress', which is in accordance with the outcomes for the Sudetic region (Kuchcik 2013). 'No heat stress' in the summit zone of the Sudetes Mountains confirms the results for the multiannual period (Miszuk et al. 2016). This also makes this region similar to the higher zones of the Tatra Mountains, where strong heat stress does not occur either (Błażejczyk \& Kunert 2010; Błażejczyk et al. 2013), even during extreme thermal periods (Krzyżewska et al. 2019).

The characteristics of biometeorological conditions in the summer of 2015 and 2018, as presented, indicate the serious impact of heat stress on the human organism in the lower areas. Therefore, because of the tourism character of the region, measures related to the mitigation of the influence of heat stress should be undertaken in order to minimize the risk of overheating to the numerous tourists visiting the region. Simultaneously, thermal comfort recorded in the summits of the Sudetes, even during the most extreme thermal periods, indicates the high climate potential of this zone in the context of tourism planning.

\section{ORCID}

Bartłomiej Miszuk (ID) https://orcid.org/0000-0003-0030-7267

\section{References}

Bartoszek, K, Wereski, S, Krzyżewska, A \& Dobek, M 2017, 'The influence of atmospheric circulation on bioclimatic conditions in Lublin (Poland)', Bulletin of Geography. Physical Geography Series, no. 12, pp. 41-49.

Black, E, Blackburn, M, Harrison, G, Hoskins, B \& Methven, J 2004, 'Factors contributing to the summer 2003 European heat wave', Weather, vol. 59 (8), pp. 217-223.

Bleta, A, Nastos, PT \& Matzarakis, A 2014, 'Assessment of bioclimatic conditions on Crete Island, Greece', Reg Environ Chang, 14 (5), pp. 1967-1981.

Błażejczyk, K, Broede, P, Fiala, D, Havenith, G, Holmer, I, Jendritzky, G \& Kampmann, B 2010,'UTCI - new index for assessment of heat stress in man', Polish Geographical Review, vol. 82, no. 1, pp. 49-71.

Błażejczyk, K \& Kunert, A 2010, 'Obciążenie cieplne organizmu człowieka podczas letnich i zimowych wędrówek po Tatrach' ['Heat load in man during Summer and Winterpedestrian tourism in the Tatry Mts.'], Nauka a zarządzanie obszarem Tatr i ich otoczeniem, vol. III, Zakopane, pp. 61-68.

Błażejczyk, K \& Kunert, A 2011, Bioclimatic principles of recreation and tourism in Poland, Polish Academy of Sciences S.
Leszczycki Institute of Geography and Spatial Organization, Warsaw.

Błażejczyk, K, Baranowski, J, Błażejczyk \& A, Szmyd, J 2013, 'Klimat i bioklimat Hali Gąsienicowej' ['Climate and Bioclimate of Hala Gąsienicowa']' in The Sucha Woda Valley in the Tatra Mts. Natural environment and its presentday transformation, eds. Z Rączkowska \& A Kotarba, Geographical Studies, vol. 239, pp. 67-95.

Błażejczyk, K, Kuchcik, M, Błażejczyk, A, Milewski, P \& Szmyd, J 2014, 'Assessment of Urban thermal stress by UTCI - experimental and modelling studies: an example from Poland', Die Erde, vol. 145 (1-2), pp. 16-33.

Błażejczyk, A, Błażejczyk, K, Baranowski, J \& Kuchcik, M 2018, 'Heat stress mortality and desired adaptation responses of healthcare system in Poland', International Journal of Biometeorology, vol. 62 (3), pp. 307-318.

Bryś, K \& Ojrzyńska, H 2016, 'Stimulating qualities of biometeorological conditions in Wrocław', Acta Geographica Lodziensis, Folia Geographica Physica, vol. 104, pp. 193-200,

Chabior, M 2011, 'Selected aspects of the bioclimate of Szczecin', Studies in Geography, vol. 47, pp. 293-300. 
Di Napoli, C, Pappenberger, F, \& Cloke, HL 2018, 'Assessing heat-related health risk in Europe via the Universal Thermal Climate Index (UTCI)', International Journal of Biometeorology, vol. 62, pp. 1155-1165.

Dong, B, Sutton, R, Shaffrey, L, Wilcox, L 2016, 'The 2015 European Heat Wave', Explaining Extremes of 2015 from a Climate Perspective, Bull Amer Meteor Soc, vol. 97 (12), pp. 57-62.

Fiala, D, Lomas, KJ \& Stohrer, M 2001, 'Computer prediction of human thermoregulatory and temperature responses to a wide range of environmental conditions', International Journal of Biometeorology, vol. 45, no. 3, pp. 143-159.

Garcia-Herrera, R, Diaz, J, Trigo, RM, Luterbacher, J \& Fischer, EM 2010, A review of the European summer heat wave of 2003, Crit Rev Environ Sci Technol, vol. 40, pp. 267-300.

Hoy, A, Hänsel, S, Skalak, P, Ustrnul, Z \& Bochnicek, O 2017, The extreme European summer of 2015 in a long-term perspective, International Journal of Climatology, vol. 37, no. 2, pp. 943-962.

Ionita, M, Tallaksen, LM, Kingston, DG, Stagge, JH, Laaha, G, Van Lannen, H, Chelcea, SM \& Haslinger, K 2017, 'The European 2015 drought from a climatological perspective', Hydrology and Earth System Sciences, vol. 21, pp. 13971419.

Institute of Geography and Spatial Organization Polish Academy of Science 2020, BioKlima. Available from: < https://www. igipz.pan.pl/bioklima.html>. [10 January 2020].

Jendritzky, G, de Dear, R \& Havenith, G 2012, 'UTCI-why another thermal index?', International Journal of Biometeorology, vol. 56 , no. 3 , pp. $421-428$.

Ketterer, C \& Matzarakis, A 2010, 'The tourism climate of Engadin, Switzerland' in Proceedings of the $7^{\text {th }}$ Conference on Biometeorology, eds. A Mazarakis, $\mathrm{H}$ Mayer \& FM Chmielewski, Albert-Ludwigs-University of Freiburg, pp. 398-403.

Kolendowicz, L, Półrolniczak, M, Szyga-Pluta, K \& Bednorz, E 2018, 'Human-biometeorological conditions in the southern Baltic coast based on the universal thermal climate index (UTCI)', Theoretical and Applied Climatology, vol. 134 (1-2), pp. 363-379.

Kornhuber, K, Ospray, S, Coumou, D, Petri, S, Petoukhov, V, Rahmstorf, S \& Gray, L 2019, 'Extreme weather events in early summer 2018 connected by a recurrent hemispheric wave-7 pattern', Environmental Research Letters, vol. 14, no. 5 , pp. 1-7.

Krzyżewska, A \& Dyer, JL 2018 'The August 2015 megaheatwave in Poland in the context of past events', Weather, vol. 73 (7), pp. 207-214.

Krzyżewska, A, Wereski, S, \& Demczuk, P 2019 'Biometeorological conditions during an extreme heatwave event in Poland in August 2015', Weather, vol. 74, pp. 1-7. Available from: <https://doi.org/10.1002/wea.3497>. [10 March 2020].

Kuchcik, M, Błażejczyk, K, Szmyd, J, Milewski, P, Błażejczyk, A Baranowski, J 2013, 'Potencjał leczniczy klimatu Polski' ['The therapeutic potential of the Polish climate'], IGIPZ PAN, Wydawnictwo Akademickie Sedno, pp. 1-272.

Lindner-Cendrowska, K 2013, 'Assessment of bioclimatic conditions in cities for tourism and recreational purposes (a Warsaw case study)', Geographia Polonica, vol. 86 (1), pp. $55-66$,

Matzarakis, A, Hammerle, M, Koch, E \& Rudel, E 2012 'The climate tourism potential of Alpine destinations using the example of Sonnblick, Rauris and Saltzburg', Theoretical and Applied Climatology, vol. 110, pp. 645-658.
Matzarakis, A, Muthers, S \& Rutz, F 2014, 'Application and comparison of UTCl and PET in temperate climate conditions', Finisterra, vol. 49, no. 98, pp. 21-31.

Milewski, P 2013, 'Application of the UTCI to the local bioclimate of Poland's Ziemia Kłodzka region', Geographia Polonica, vol. 86 , no. 1, pp. 47-54.

Miszuk, B, Otop, I, Strońska, M, Schwarzak, S \& Surke, M 2016, 'Tourism-climate conditions and their future development in the Polish-Saxon border area', Meteorologische Zeitschrift, vol. 25 (4), pp. 421-434.

Muthers, S, Laschewski, G \& Matzarakis, A 2017, 'The summers 2003 and 2015 in South-West Germany: Heat waves and heat-related mortality in the context of climate change', Atmosphere, vol. 8 (11). Available from: <https://www.mdpi. com/2073-4433/8/11/224>. [10 March 2020].

Nemeth, A 2011, 'Changing thermal bioclimate in some Hungarian cities', Acta Climatologica et Chorologica Universitatis Szegediensis, vol. 44-45, pp. 93-101.

Novak, M 2013, 'Use of the UTCI in the Czech Republic', Geographia Polonica, vol. 86, no. 1, pp. 21-28.

Nowosad, M, Rodzik, B, Wereski, S \& Dobek, M 2013, 'The UTCI Index in Lesko and Lublin and its circulation determinants', Geographia Polonica, vol. 86, no. 1, pp. 29-36.

Pecelj, M, Đorđević, A, Pecelj, M, R, Pecelj-Purković, J, Filipović, D \& Šećerov, V 2017, 'Biothermal conditions on Mt. Zlatibor based on thermophysiological indices', Archives of Biological Sciences, vol. 69, no. 3, pp. 455-461.

Plavcová, E \& Kyselý, J 2016, 'Overly persistent circulation in climate models contributes to overestimated frequency and duration of heat waves and cold spells', Climate Dynamics, vol. 46 (9-10), pp. 2805-2820.

Rozbicka, K \& Rozbicki, T, 2018, 'Variability of UTCI index in South Warsaw depending on atmospheric circulation', Theoretical and Applied Climatology, vol. 133, no. 1-2, pp. 511-520.

Ragettli, MS, Schindler, C \& Röösli, M 2017, 'Excess mortality during the warm summer of 2015 in Switzerland', Swiss Medical Weekly, vol. 146

Russo, S, Sillmann, J \& Fischer, EM 2015, 'Top ten European heatwaves since 1950 and their occurrence in the coming decades', Environmental Research Letters, vol. 10, no. 12.

Sobolewski, R 2018, 'Ocena warunków aerosanitarnych i bioklimatycznych Legnicy' ['Evaluation of aerosanitary and bioclimate conditions in Legnica'], Przestrzeń Dolnego Śląska w badaniach naukowych, IRT. Available from: <https://irt.wroc.pl/aktualnosc-26-511-seminarium inaugurujace_cykl_pt.html>. [03 May 2020].

Sulikowska, A, Wypych, A \& Woszczek, I 2016, 'Fale upałów latem 2015 roku i ich uwarunkowania cyrkulacyjne' ['The 2015 summer heat waves in Poland and their synoptic background'], Badania Fizjograficzne, VII, Seria A, Geografia Fizyczna (A67), pp. 205-223.

The Royal Netherlands Meteorological Institute 2020. Available from: <https://www.knmi.nl/over-het-knmi>. [10 March 2020].

Tomczyk, AM \& Bednorz, E 2020, 'The extreme year-analysis of thermal conditions in Poland in 2018', Theoretical and Applied Climatology, vol. 139, pp. 251-260.

Tomczyk, AM \& Owczarek, M 2020, Occurrence of strong and very strong heat stress in Poland and its circulation conditions', Theoretical and Applied Climatology, vol. 139, pp. 893-905.

Urban, A \& Kyselý , J 2014, 'Comparison of UTCI with other thermal indices in the assessment of heat and cold effects on cardiovascular mortality in the Czech Republic', 
MISCELLANEA GEOGRAPHICA - REGIONAL STUDIES ON DEVELOPMENT

Vol. $24 \cdot$ No. $3 \cdot 2020 \cdot$ pp. 138-146 • ISSN: 2084-6118 • DOI: 10.2478/mgrsd-2020-0020

International Journal of Environmental Research and Public Health, vol. 11 (1), pp. 952-967.

Urban, A, Hanzlikova, H, Kyselý , J \& Plavcova, E 2017, 'Impacts of the 2015 Heat Waves on Mortality in the Czech Republic-A Comparison with Previous Heat Waves', International Journal of Environmental Research and Public Health, vol. 14 (12). Available from: <https://www.mdpi. com/1660-4601/14/12/1562>. [10 March 2020].

Wetter3 2020. Available from: <http://www1.wetter3.de/index_ dt.html>. [10 March 2020].

Wibig, J 2018, 'Heat waves in Poland in the period 1951-2015: trends, patterns and driving factors', Meteorology Hydrology and Water Management, vol. 6, no 1, pp. 37-45.

WMO, 2019, The Global Climate 2015-2019. World Meteorological Organization. Available from: <library.wmo. int>. [23 January 2020]. 